\title{
ogopaedica
ogziensia
}

$\mathrm{Nr} 4(2020)$

DOl: http://dx.doi.org/10.18778/2544-7238.04.14

Marzena Maria Szurek* iD

\section{Budowa graficzna pisma oraz zaburzenia w strukturze wyrazów na przykładzie wybranych próbek tekstów pisanych przez dorosłe osoby z dysleksją}

The Graphic Construction of the Handwriting and Disorders in the Word Structure on the Example of Selected Text Samples Written by Adults with Dyslexia

\section{Słowa kluczowe: dysleksja, dysleksja u dorosłych, dorosła osoba z dysleksją, dysgrafia, dysortografia, objawy dysleksji, zaburzenia systemu fonologicznego i morfologicznego, zaburzenia struktury wyrazu}

Keywords: dyslexia, dyslexia in adults, adult with dyslexia, dysgraphia, dysortography, symptoms of dyslexia, disorders of the phonological and morphological system of language, word structure disorders

\section{Wprowadzenie}

O dysleksji mówi się dzisiaj dużo i często. Literatura pedagogiczna i psychologiczna zajmują się tym tematem szczególnie od strony skutecznej diagnozy i terapii, która powinna być podejmowana w przypadku uczniów z dysleksją [Bogdanowicz, 1995; 1996; 1999; 2002; 2005b; 2008a; 2011a; 2011b; Nijakowska, 2004; Cieszyńska, 2005; Bogdanowicz, Adryjanek, Różyńska, 2007; Bogdanowicz, Czabaj, Bućko, 2008; Krasowicz-Kupis, 2009a; 2009b; Czabaj, 2010; Kurowska, 2011]. Również w serwisach internetowych i prasie, nie tylko tej skierowanej do nauczycieli, znaleźć można opinie ekspertów, szczegółowe opisy objawów i strategie postępowania wobec uczniów ze specyficznymi trudnościami w uczeniu się, ale często też dyskusje na temat skali zjawiska. Niestety, przekaz medialny dotyczący tego zaburzenia często zaciemnia i fałszuje rzeczywisty obraz problemu [por. Chodyna-Santus, 2014].

\footnotetext{
* Akademia Ignatianum w Krakowie, Wydział Pedagogiczny, Instytut Nauk o Wychowaniu, Zakład Logopedii i Pedolingwistyki, ul. Kopernika 26, 30-501 Kraków, e-mail: marzena.szurek@ignatianum. edu.pl, ORCID: https://orcid.org/0000-0002-8134-2285.
} 
Zastanawiające jest to, że o dysleksji mówi się prawie wyłącznie w kontekście uczniów i problemów szkolnych. Zaskakuje też przekonanie, że z dysleksji się wyrasta [Kowaluk-Romanek, 2016, s. 307]. Wydaje się więc, że nie jest to temat na tyle często poruszany, aby trwanie zaburzeń o typie dyslektycznym również w wieku dorosłym stało się czymś oczywistym. O tym, że jest to problem na całe życie, czytamy w niektórych pracach Marty Bogdanowicz [np. 2005; 2009]. Wspólnie z Grażyną Krasowicz-Kupis odniosła się ona również do kwestionariusza objawów dysleksji u dorosłych Michaela Vinegrada [Bogdanowicz, Krasowicz-Kupis, 2000]. Temat ten szczególnie mocno wybrzmiał w książce Portrety nie tylko sławnych osób $z$ dysleksją [Bogdanowicz, 2008b]. Natomiast w 2010 roku w „Biuletynie Polskiego Towarzystwa Dysleksji” opublikowany został artykuł dotyczący objawów dysleksji u studentów [Bogdanowicz, Bogdanowicz, Pąchalska, 2010, s. 2-14]. Temat dysleksji u dorosłych jest wyraźnie obecny w publikacjach Katarzyny Bogdanowicz [2008; 2011a], która deklaruje się jako dorosła osoba dyslektyczna [2011b]. Najobszerniejsza jej praca poświęcona tej kwestii to książka wydana wspólnie z Martą Łockiewicz [Łockiewicz, Bogdanonwicz, 2013]. Najnowszą publikacją dotyczącą etapu postszkolnego jest książka Teresy Wejner-Jaworskiej [2019]. Jednak wymienione publikacje i ich odniesienia do wieku dorosłego są jedynie wyimkiem na tle szeroko dostępnej polskojęzycznej literatury dotyczącej dysleksji. Koncentrowanie się głównie na trudnościach szkolnych jest poniekąd zrozumiałe i może wynikać w sposób nieuświadomiony z obowiązujących definicji omawianego zaburzenia [zob. np. ICD-10, 2000 oraz DSM-5. Diagnostic and Statistical Manual of Mental Disorders, 2013], które - w celu zdefiniowania tegoż - operują siatką pojęciową o określonych polach semantycznych. Te natomiast automatycznie odsyłają czytelnika do sfery szkoły i uczenia się. Sprzyja temu również nazewnictwo związane z dysleksją: learning disability, specific learning disability, specific learning disorder oraz kryteria diagnostyczne [zob. ICD-10, 2000; DSM-5..., 2013] dotyczące trudności związanych z takimi dziedzinami funkcjonowania człowieka, które Krasowicz-Kupis [2009a, s. 22] nazywa „szkolnymi” lub „akademickimi”. Ponadto czynności czytania i pisania, do których odwołuje się większość charakterystyk objawowych w kontekście dysleksji i które uważane są powszechnie za główne (często też niestety za jedyne) symptomy tego zaburzenia, też kojarzą się nieodmiennie z rzeczywistością szkolną ${ }^{1}$.

Głównym celem artykułu jest zwrócenie uwagi na problemy funkcjonowania językowego osób dorosłych z dysleksją (zwłaszcza w sferze języka pisanego), ale też pośrednio podkreślenie wieloaspektowości zaburzeń o proweniencji dyslektycznej w kontekście wieku dorosłego. Przedmiotem rozważań są wybrane próbki tekstów. U ich autorów w przeszłości (w okresie przypadającym na lata nauki szkolnej lub później) zdiagnozowano specyficzne trudności w uczeniu się. Grupa badanych - składająca się z trzech dorosłych już osób z dysleksją - została dobrana w taki sposób, aby zaprezentować szeroki

1 Kwestia ta nie jest przedmiotem niniejszego opracowania, dlatego nie będę jej szerzej rozwijać. O nieadekwatności sprowadzania dysleksji wyłącznie do deficytów w zakresie nauki czytania i pisania pisałam w artykule Dysleksja istnieje naprawdę! - Jak ją rozpoznać i zrozumieć [Szurek, 2014]. 
przedział wiekowy (student, trzydziestoletni mężczyzna oraz osoba w wieku sześćdziesięciu lat), a jednocześnie podkreślić nieprzemijalność specyficznych cech pisma, które są charakterystyczne dla omawianego zaburzenia. Analiza ma w zasadzie charakter synchroniczny, ale w przypadku opisu strony graficznej pisma zastosowana została perspektywa longituidalna, gdyż teksty dojrzałe zestawiono z tekstami z okresów dzieciństwa i wczesnej młodości tej samej osoby. Na tej podstawie wskazano cechy charakterystyczne tekstów pisanych, zawężając eksplikację do grafii oraz zaburzeń struktury wyrazów, które można wpisać w obręb deficytów systemu morfologicznego i fonetyczno-fonologicznego. Wszystkie cechy pozostają niezmienne niezależnie od wieku. O ile aspekt graficzny pisma wraz z ortografią to najczęściej opisywane kwestie w kontekście zaburzeń dyslektycznych, o tyle dwa ostatnie systemy wydają się sferą wymagającą dokładniejszego opracowania. Należy też zaznaczyć, że w przypadku wielu błędów popełnianych przez dyslektyków trudno o jednoznaczną językoznawczą kwalifikację do określonej kategorii. Te same deficyty można na przykład rozpatrywać jednocześnie jako problem na poziomie morfologicznym oraz ortograficznym. Dlatego interpretacja językoznawcza zaprezentowanych poniżej tekstów pisanych wymaga pewnej umowności opisu.

\section{Kłopotliwe pismo, czyli verba volant, scripta manent}

Cechą wspólną wszystkich dorosłych dyslektyków jest nieestetyczny charakter pisma, które jest słabo czytelne lub nieustabilizowane graficznie. Dotyczy to nie tylko liter, ale wszelkich znaków graficznych, także liczbowych. Ów brak stabilności graficznej - zaburzenie proporcji i zmiany kierunku pochylenia cyfr i liter oraz niewłaściwe łączenie tych ostatnich - jest charakterystyczny dla dzieci opanowujących dopiero precyzję ruchów i mechanizmy odpowiedzialne za sprawność grafomotoryczną. Jednak w przypadku osób dyslektycznych grafomotoryka i umiejętność estetycznego rozplanowania poszczególnych elementów w perspektywie całości zapisu nigdy nie zostają dostatecznie opanowane. Widać to na przykładzie poniższego zestawienia próbek tekstów tej samej osoby, które pochodzą z różnych okresów jej życia.

We wszystkich zaprezentowanych tekstach, niezależnie od zmieniającego się wieku ich autora, obecne są typowe błędy graficzne, wyróżnione przez Tadeusza Wróbla w pracy poświęconej pismu i pisaniu na etapie nauczania początkowego [Wróbel, 1979, s. 92-95]. Należą do nich, bardzo tu widoczne, deficyty konstrukcyjne polegające na naruszeniu kształtu litery w porównaniu z jej wzorem, na zachwianiu proporcji oraz zniekształceniu linii. Widzimy też brak proporcjonalności, odzwierciedlony w niejednolitym zagęszczeniu znaków, różnej ich wielkości, wysokości i zachowaniu linii prostej względem płaszczyzny poziomej, a wreszcie na braku jednolitych odstępów między literami i wyrazami. Wyraźnie zauważalne są też zmiany kierunku pochylenia poszczególnych znaków (liter, cyfr) [por. Czelakowska, 2012, s. 113]. W zestawieniu powyższych próbek nieprzypadkowo znalazły się również zapisy działań 
matematycznych, problemy w linearnym uporządkowaniu elementów symbolicznych dotyczą bowiem również cyfr i innych symboli [por. Cieszyńska-Rożek, 2010, s. 40].

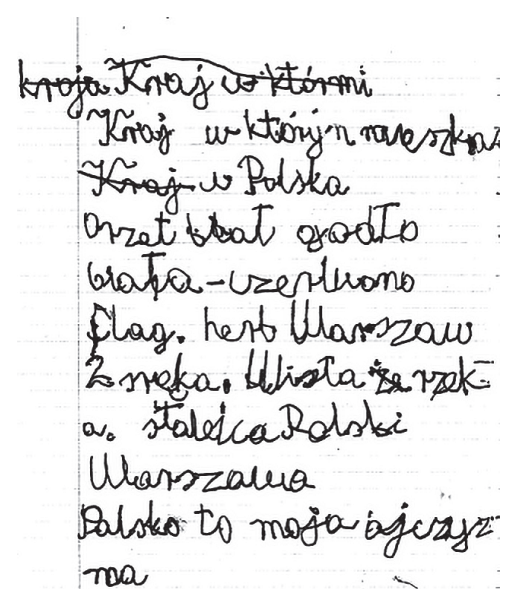

Ilustracja 1. III klasa szkoły podstawowej

Źródło: archiwum własne.

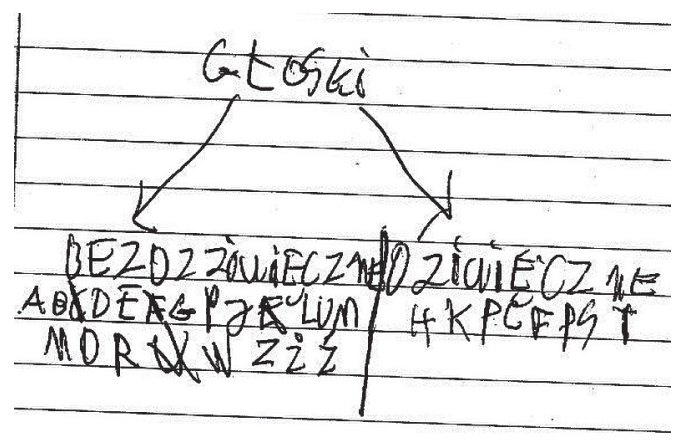

Ilustracja 3. I klasa gimnazjum

Źródło: archiwum własne.

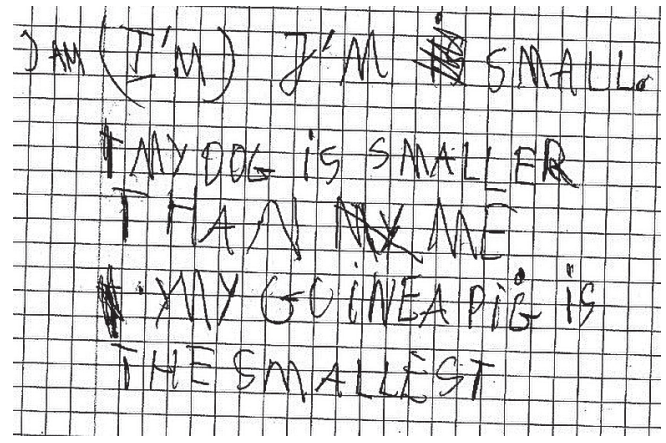

Ilustracja 2. V klasa szkoły podstawowej Źródło: archiwum własne.

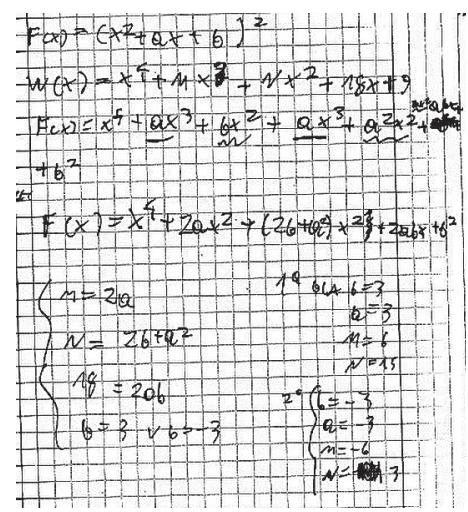

Ilustracja 4. Pierwsze lata nauki w liceum Źródło: archiwum własne.

Sposobem na radzenie sobie z opisanymi wyżej kłopotami natury graficzno-estetycznej jest taktyka stosowania pisma wersalikowego, które - przez swoją prostotę - jest bardziej czytelne. Co więcej, nie wymaga łączenia znaków oraz dodatkowo wyłącza konieczność rozróżniania w zakresie zasad stosowania wielkich i małych liter. Jak wynika z zaprezentowanych próbek tekstowych, zabieg ów został uskuteczniony tuż po zakończeniu kształcenia na etapie początkowym (klasy 1-3), kiedy to strona techniczna pisma, kształt i sposób łączenia liter nie są już kwestią traktowaną priorytetowo przez nauczycieli. Ten rodzaj maskowania problemów z grafią to taktyka realizowana przez większość osób z dysleksją. Potwierdzenie tego znajdujemy 
również w jednej z książek M. Bogdanowicz: „Moje kłopoty w dużej mierze się skończyły, kiedy wpadłem na pomysł, żeby pisać drukowanymi literami” - mówi Maciej Kuroń, cytowany przez autorkę [Bogdanowicz, 2008b, s. 76]. Innym rozwiązaniem stosowanym przez dorosłych dyslektyków jest używanie pisma technicznego, zachowującego podział na małe i wielkie litery, ale pozbawionego łączeń, co obrazuje poniższy dokument, będący fragmentem wypowiedzi pisemnej osoby dorosłej, u której objawy dysleksji mają charakter w dużej mierze skompensowany.

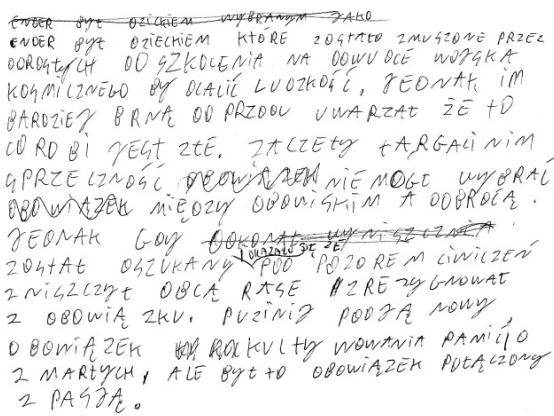

Ilustracja 5. Klasa maturalna

Źródło: archiwum własne.

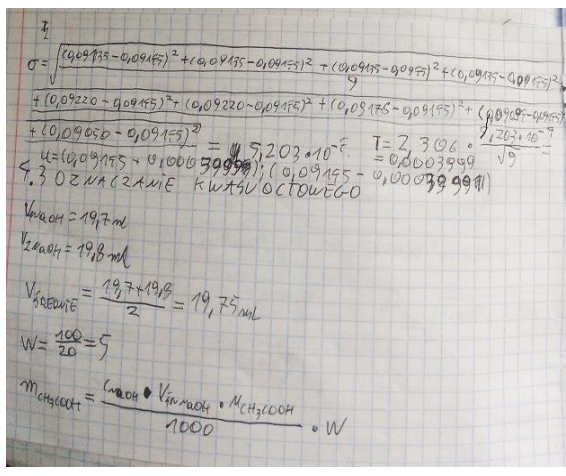

Ilustracja 6. Okres studiów wyższych

Źródło: archiwum własne.

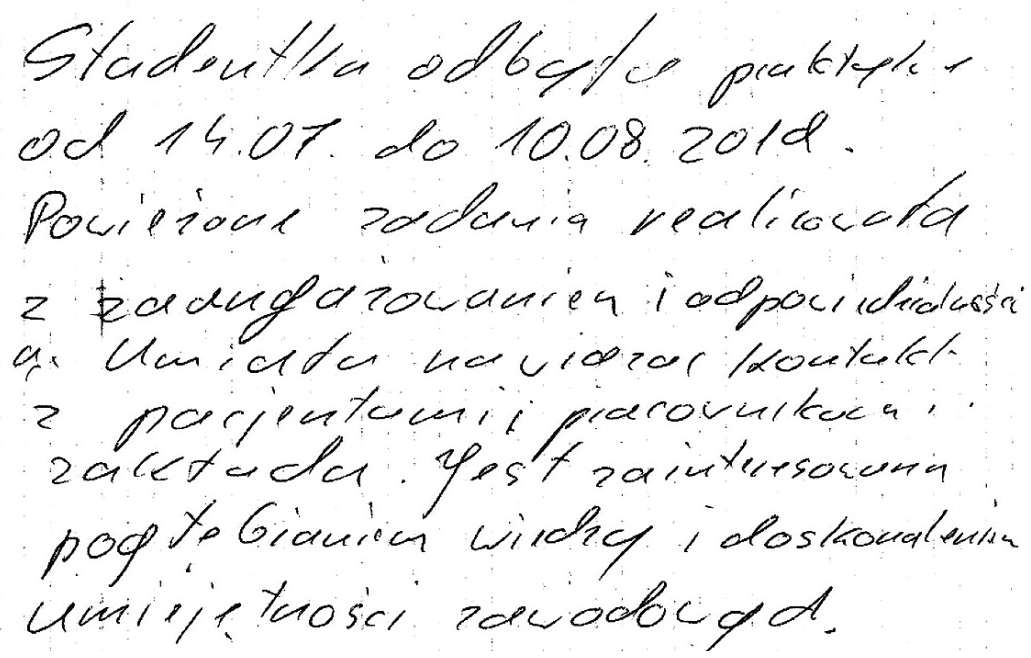

Ilustracja 7. Strategia stosowania pisma technicznego

Źródło: archiwum własne.

U dyslektyków problem z koordynacją wzrokowo-ruchową jest do tego stopnia nasilony, że dotyczy nawet własnego podpisu. Osoby te nie tylko nie są w stanie wypracować indywidualnego charakteru pisma, ale też zautomatyzować stałego 
autografu [Bogdanowicz, 2011a, s. 75-76]. Jacek Żakowski - jeden z bohaterów książki Portrety nie tylko sławnych osób $z$ dysleksją, tak opisuje swoje doświadczenia w tym zakresie:

Nie wyrobiłem sobie stałego podpisu. Byłem swego czasu prezesem Polskiej Agencji Informacyjnej [...] i w tym charakterze podpisywałem czeki. Banki odsyłały je, bo podpisywałem się za każdym razem inaczej. Musiałem dać komuś pełnomocnictwo [Bogdanowicz, 2008b, s. 170].

Graficzną kwestią pisma są także problemy z ortografią, będące objawami najczęściej kojarzonymi z dysleksją. Oczywiste jest, że kłopoty z ortografią dotyczą również osób dorosłych², jako że mózg głęboko dyslektyczny najczęściej nie jest w stanie zapamiętać i wyabstrahować reguł związanych z tą sferą języka pisanego ${ }^{3}$. Jak bardzo głęboki i trwały jest to problem, obrazują zaprezentowane poniżej próbki tekstu. Pierwsze dwa przykłady to fragmenty notatek dwudziestoletniego studenta, który przez cały okres nauki szkolnej (podczas wszystkich etapów systemu edukacji) poddawany był intensywnej terapii i wspomaganiu pod kątem zminimalizowania skutków dysleksji. Autorem ostatniego tekstu jest trzydziestoletni mężczyzna, u którego proces terapii trwał do momentu zakończenia nauki w gimnazjum.

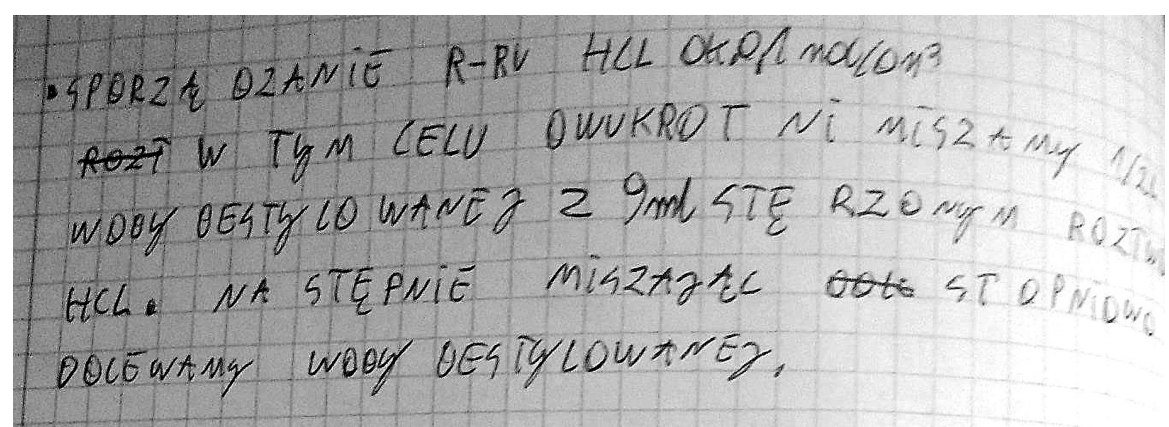

Ilustracja 8. Problemy z ortografią u osoby 20-letniej

Źródło: archiwum własne.

2 Mowa tu o ogromnej większości przypadków, aczkolwiek niektórzy dorośli dyslektycy, u których objawy nie mają charakteru głębokich zaburzeń lub nakierowane są na inną sferę poznawczą (dotyczącą np. liczb i operacji matematycznych), mogą w pewnym stopniu opanować reguły ortograficzne. Jednakże, jak sami mówią, często odczuwają dyskomfort z powodu pojawiania się tak zwanych czarnych dziur w głowie, polegających na przykład na niemożności przypomnienia sobie ortograficznej zasady związanej z zapisem jakiegoś konkretnego wyrazu (najczęściej jest to zawsze ten sam wyraz lub wyrazy). 3 W tym kontekście należy zadać pytanie, czy stosowanie (wciąż niestety aktualne) przez pedagogów działań kompensacyjno-wyrównawczych na zasadzie wielokrotnego przepisywania tych samych wyrazów i zdań z daną regułą ortograficzną, wypełniania ćwiczeń ortograficznych oraz pisania dyktand ma jakikolwiek sens. Korendo [2009, s. 235-236] określiła ten niefortunny sposób działania jako „«leczenie» dysleksji poprzez ćwiczenia obserwowanych objawów”. 


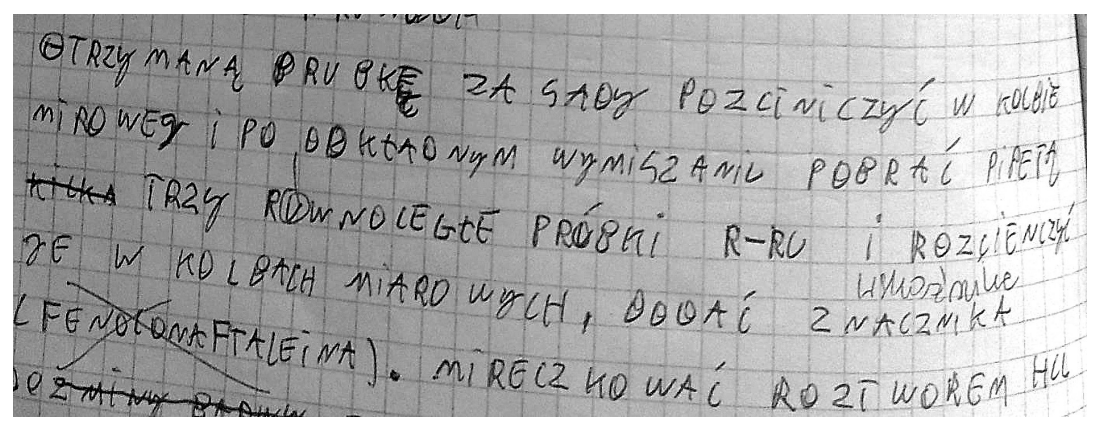

Ilustracja 9. Problemy z ortografią u osoby 20-letniej

Żródło: archiwum własne.

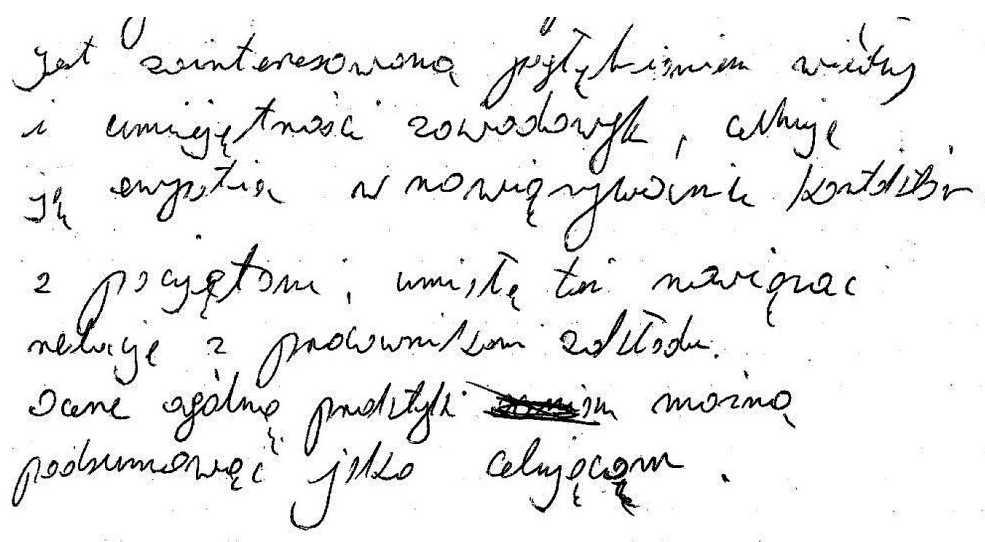

Ilustracja 10. Problemy z ortografią u osoby 30-letniej

Źródło: archiwum własne.

Nienormatywna grafia (w tym ortografia) to wcale nie jedyny wyznacznik deficytów związanych z dyslektycznym pismem. Błędy w zapisie polegają też na charakterystycznych aberracjach fonetycznych, co jest szczególnie widoczne w poniższym tekście maturzysty.

Autor zapisu wykazuje dowolność, jeśli chodzi o oznaczanie palatalności, wymiennie stosuje w tym celu znak diakrytyczny oraz literę $i$, która także może występować w funkcji oznaczania miękkości poprzedniej spółgłoski (zakreślenia). Ponadto tekst pokazuje tendencję do odzwierciedlania na piśmie formy dźwiękowej wyrazu (takiej, jaką słyszymy, wymawiając go), jest to zatem zapis fonetyczny, a nie ortograficzny. Taki rodzaj zapisu jest częsty w przypadku wyrazów zawierających samogłoskę nosową w wygłosie lub w śródgłosie przed głoskami szczelinowymi. W wyżej zamieszczonej próbce tekstu (pierwsze zakreśleniu) widoczny jest w pierwszej kolejności zapis odzwierciedlający zdenazalizowaną oraz zlabializowaną wymowę wygłosowej samogłoski nosowej ą. Poniżej natomiast (ostatnie zakreślenie) widzimy wtórnie powstałą samogłoskę nosową ę, znajdującą się przed spółgłoską szczelinową $s$. 
WALZUT ZYÝ NA NOWD TAKJAK CHLIAT.

YELELEE INNA SYTU ACYE PRZO

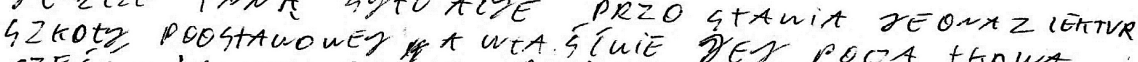

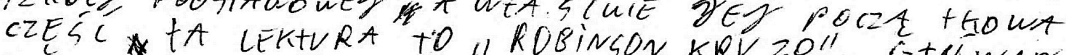

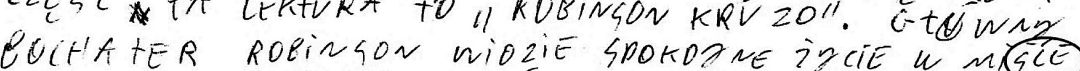
PURTQUYM. YEONAK COS LA TY CZ AS KO WRELZL.

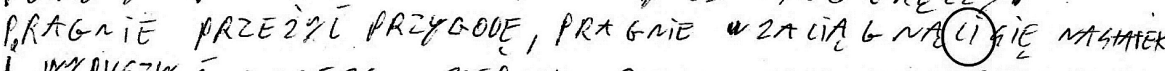

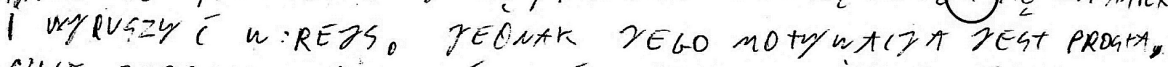
CHLE ROPROSH W UOLÉ COG NIESAMOWITEGO. JEONAK

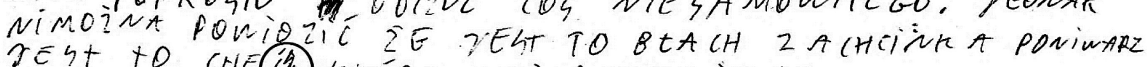
TEST to CHE(Mi) KTOKA ZMINI YEGO ZYCIE.

PRALA, PASIA IZY OQOWIA ZEK? NIEOA GIE WIBRAÉ YEONEA Z TYCH OPCII TAK PORROSTV. WhZIY GTKI GIE ONE $2 E 408 A$ MOGA A ALE NINULZA PRZEPCATAĆ. OCZYWISL MO MOZENY

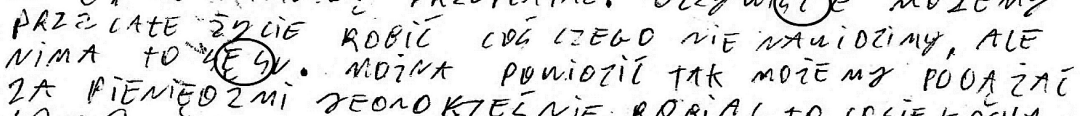
UOMNOD. PREAA, JEONOKZESNIE: ROGIAC TO. COSIE KOCHA

Ilustracja 11. Błędy o charakterze fonetycznym

Źródło: archiwum własne.

Wiele nieprawidłowości dotyczy struktury morfologicznej wyrazów. W analizowanych przeze mnie tekstach przybierają one najczęściej formę elizji samogłoski $e$. Dzieje się tak konsekwentnie w przypadku bezpośredniego sąsiedztwa z samogłoską $i$, co obrazuje kolejny fragment:

2ACZYM WREY LIV GONIA WOZIE?QA IA PASZA? PIENIED ZMI? SAMT CZY POOARZAZA ZA OBO WiA FIM KTÓRY GOBIE SAMI NA RZVCICI CUB NARZVCITO VE IM SPOTECZENISTUP.

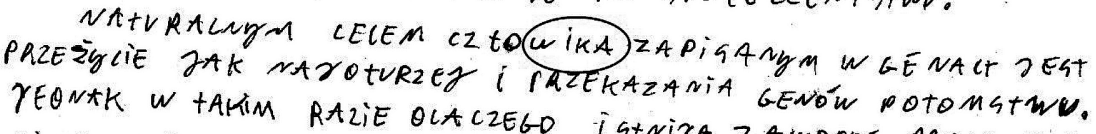
PIENIAOZE? OO POWIC TEGT PRAGNAí CZEGÓ́ WIELEY. CZYG PAOSTA. WOOZI ZaCZELI

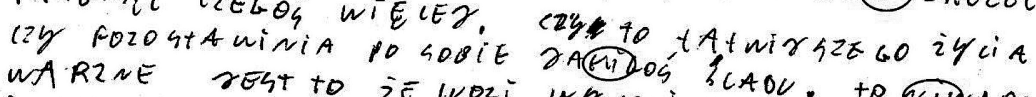
WARZNE rEST tO $Z \bar{E}$ WOZI WYSZLI LOAOU. TO NIDARZNE: ... ... - SWOJE rik LOfNE

Ilustracja 12. Błędy o charakterze morfologicznym (elizje)

Źródło: archiwum własne.

Innym rodzajem aberracji morfologicznej jest rozbijanie całościowych form wyrazowych na dwie części, analogicznie do wyrażeń przyimkowych, jak na przykładzie: 


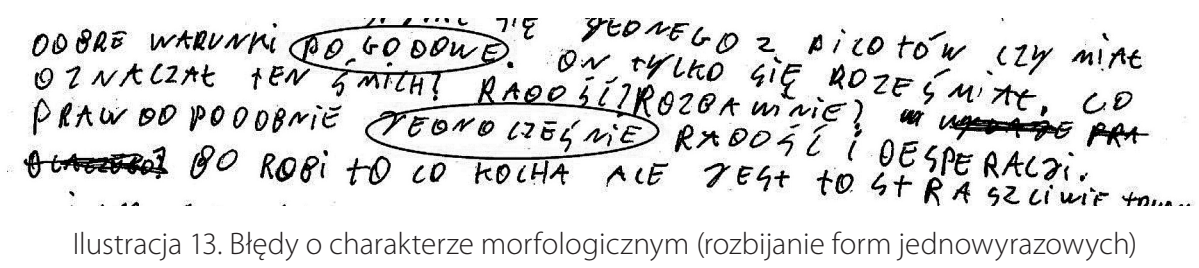

Źródło: archiwum własne.

\section{Wnioski i zakończenie}

Powyższe omówienie dotyczy tylko wybranych aspektów języka pisanego dorosłych osób z dysleksją. Faktem jest, że zniekształceniom ulegają też inne podsystemy - składniowy oraz leksykalno-semantyczny, choć ten ostatni dotyczy głównie odchyleń na szczeblu szeroko pojętej stylistyki. Zaburzenia obecne są zatem w tekstach dorosłych dyslektyków na poziomie wyrazu i zdania, a także w warstwie tekstu jako większej całości. Ze względów oczywistych nie można zrównywać tekstów dzieci i młodzieży w wieku szkolnym z tekstami dorosłych osób z dysleksją. Ci ostatni wypracowują wiele strategii maskujących, zastępczych lub kompensacyjnych. Pewne cechy pozostają jednak niezmienne. Przedstawiona w niniejszym opracowaniu analiza tekstów pokazuje trwałość wielu zjawisk związanych z nieprawidłowym przetwarzaniem języka. Świadczy to o tym, że dysleksja nie znika wraz z ukończeniem zinstytucjonalizowanej nauki szkolnej. Może mieć jedynie charakter skompensowany [por. Bogdanowicz, 2009]. Specyficzne deficyty związane z językiem, nawet w przypadku znacznej kompensacji w zakresie pisma, manifestują się często podczas mówienia i przetwarzania mowy. Przejawiają się na przykład w gubieniu wątku, przejęzyczeniach, przekręcaniu nazwisk i nazw, ale też zasłyszanych faktów (co wynika z uruchamiania mechanizmu schematyczności i projekcji). Obserwowane są też trudności ze zrozumieniem wypowiedzi innych ludzi, zwłaszcza w hałasie lub w sytuacji napięcia emocjonalnego (częste dopytywanie, prośby o powtórzenie albo mechaniczne przytakiwanie mimo braku rozumienia).

$\mathrm{Na}$ koniec warto podkreślić, że dysleksja w wieku dorosłym dotyczy także innych, pozajęzykowych sfer funkcjonowania człowieka. Odnosząc się do profilu charakterologicznego tych osób, można określić je najogólniej jako roztargnione lub - potocznie mówiąc - „zakręcone"4. Jest to związane między innymi ze słabą samoorganizacją lub nieumiejętnością zarządzania czasem. Stąd częste spóźnianie się, zapominanie czy gubienie rzeczy. Do innych cech obecnych w zachowaniu i funkcjonowaniu dorosłych dyslektyków mogą należeć [por. Szurek, 2014, s. 167]:

4 Słownik języka polskiego PWN oprócz znaczenia dosłownego podaje dwa potoczne wyjaśnienia przymiotnika zakręcony: 'szalony lub niesamowity' oraz właśnie 'roztargniony'. 
- ogólna nieporadność życiowa;

- mylenie kierunków (trudność z odróżnianiem strony prawej od lewej) i brak orientacji w nieznanym terenie, gubienie drogi [Bogdanowicz, 2009];

- mylenie numerów (np. numerów autobusów, telefonów) oraz dat i godzin [por. Bogdanowicz, 2009];

- problemy z posługiwaniem się pieniędzmi i z bezbłędnym odczytywaniem godzin, szczególnie na zegarkach analogowych;

- kłopoty z koordynacją ruchową, na przykład przy próbie opanowania układów gimnastycznych lub tanecznych [Bogdanowicz, 2009];

- słabe radzenie sobie z rozumieniem zasad wypełniania wszelkich formularzy urzędowych [Bogdanowicz, 2009];

- zapominalstwo, zaburzona pamięć krótkotrwała [por. Łockiewicz, Bogdanowicz, 2013];

- nieobecność mentalna, brak koncentracji, nieumiejętność podzielności uwagi [Buchholz, Davies, 2005], zwłaszcza w sytuacjach stresowych lub w chwilach gorszej kondycji psychicznej;

- tendencja do stanów depresyjnych i niskiego poczucia własnej wartości, a nawet samoagresji [Krasowicz-Kupis, 2009a, s. 162, 164 i 167; Szurek, 2014, s. 169-171].

Charakterystyczne dla dorosłych osób dyslektycznych jest również to, że częściej niż u pozostałych spotykany jest u nich lewostronny lub skrzyżowany model lateralizacji stronnej, a nierzadko tendencja do oburęczności5 . W przypadku osób, których lata nauki szkolnej przypadały na okres nieistnienia dysleksji w świadomości pedagogicznej, częste są sytuacje wymuszonej praworęczności, co dodatkowo intensyfikuje skalę deficytów, zwłaszcza w kontekście problemów dysgraficznych.

\section{Literatura}

Bogdanowicz K., 2008, W czepku urodzona, czyli portret szczęśliwego dyslektyka,

[w:] M. Bogdanowicz (red.), Portrety nie tylko znanych osób z dysleksją, Gdańsk: Wydawnictwo Harmonia, s. 261-269.

Bogdanowicz K., 2011a, Dysleksja a nauczanie języków obcych. Przewodnik dla nauczycieli i rodziców uczniów z dysleksją, Gdańsk: Wydawnictwo Harmonia.

Bogdanowicz K., 2011b, Mam dysleksję i nie zawaham się jej użyć, „Gazeta Wyborcza”, 18.11, strony lokalne GW - Gdańsk, nr 268, s. 12.

Bogdanowicz K., Bogdanowicz M., Pąchalska M., 2010, Studenci z dysleksja i ich słabe strony, „Dysleksja. Biuletyn Polskiego Towarzystwa Dysleksji”, nr 1(6), s. 12-14.

Bogdanowicz M., 1995, Uczeń o specyficznych potrzebach edukacyjnych, „Psychologia Wychowawcza", nr 3, s. 216-133.

$5 \mathrm{Na}$ temat znaczenia lateralizacji w rozwoju kompetencji językowych pisałam w artykule Structural and Functional Asymmetries in the Brain in the Light of Lateralization and Development of Language Competences [Szurek, 2014]. 
Bogdanowicz M., 1996, Specyficzne trudności w czytaniu i pisaniu u dzieci - nowa definicja i miejsce w klasyfikacjach międzynarodowych, „Psychologia Wychowawcza”, nr 1, s. 13-23.

Bogdanowicz M., 1999, Model kompleksowej pomocy osobom z dysleksja rozwojowa - ocena stanu aktualnego i propozycje zmian w świetle reformy systemu edukacji, „Psychologia Wychowawcza”, nr 3, s. 217-227.

Bogdanowicz M., 2002, Recepty na dobre czytanie i pisanie, [w:] W. Turewicz (red.), Jak pomóc dziecku z dysortografią, Zielona Góra: Ośrodek Doskonalenia Nauczycieli, s. 39-50.

Bogdanowicz M., 2005a, Dysleksja problemem całego życia, [w:] M. Sinica, A. Rudzińska-Rogoża (red.), W kręgu specyficznych trudności w uczeniu się czytania i pisania, Zielona Góra: Uniwersytet Zielonogórski, s. 7-21.

Bogdanowicz M., 2005b, Ryzyko dysleksji. Problem i diagnozowanie, Gdańsk: Wydawnictwo Harmonia.

Bogdanowicz M., 2008a, Model diagnozowania dysleksji rozwojowej, „Dysleksja. Biuletyn Polskiego Towarzystwa Dysleksji”, numer sygnalny, s. 7-12.

Bogdanowicz M., 2008b, Portrety nie tylko sławnych osób z dysleksją, Gdańsk: Wydawnictwo Harmonia.

Bogdanowicz M., 2009, Dysleksja u osób dorostych, [w:] I. Sosin, M. Matraszek (red.), Zeszyt terapeuty. Edukacja - profilaktyka - terapia, Warszawa: Polskie Towarzystwo Dysleksji, Warszawski Oddział nr 1, Centrum Wspomagania Rozwoju Osobowości, s. 52-61.

Bogdanowicz M., 2011a, Kwestionariusz rozpoznawania ryzyka specyficznych trudności w czytaniu i pisaniu u uczniów rozpoczynających naukę w II, III klasie, Gdynia: Wydawnictwo Operon.

Bogdanowicz M., 2011b, Ryzyko dysleksji, dysortografii i dysgrafii - Skala Ryzyka Dysleksji wraz z normami dla klas I i II, Gdańsk: Wydawnictwo Harmonia Universalis.

Bogdanowicz M., Krasowicz-Kupis G., 2000, Kwestionariusz objawów dysleksji u dorostych Michaela Vinegrada, [w:] W. Turewicz (red.), Jak pomóc dziecku z dysortografia, Zielona Góra: Ośrodek Doskonalenia Nauczycieli, s. 25-27.

Bogdanowicz M., Adryjanek A., Różyńska M., 2007, Uczeń z dysleksją w domu. Poradnik nie tylko dla rodziców, Gdańsk: Wydawnictwo Operon.

Bogdanowicz M., Czabaj R., Bućko A., 2008, Modelowy system profilaktyki i pomocy psychologiczno-pedagogicznej uczniom $z$ dysleksja rozwojowa, Gdynia: Wydawnictwo Operon.

Bucholz J., Davies A.A., 2005, Adults with dyslexia demonstrates space-based and object-based covert attention deficits: Shifting attention to the periphery and shifting attention between objects in the left visual field, „Brain and Cognition”, t. 57(1), s. 30-34.

Cieszyńska J., 2005, Nauka czytania krok po kroku. Jak przeciwdziałać dysleksji, Kraków: Wydawnictwo Naukowe Uniwersytetu Pedagogicznego.

Cieszyńska-Rożek J., 2010, Zaburzenia linearnego porzadkowania, czyli dysleksja, [w:] J. Cieszyńska, Z. Orłowska-Popek, M. Korendo (red.), Nowe podejście w diagnozie i terapii logopedycznej - metoda krakowska, Kraków: Wydawnictwo Naukowe Akademii Pedagogicznej, s. 37-51.

Chodyna-Santus M., 2014, Dysleksja w mediach, https://repozytorium.ukw.edu.pl/handle/item/1710 (dostęp: 30.10.2019).

Czabaj R., 2010, Rozpoznanie i wspomaganie uczniów ze specyficznymi trudnościami w uczeniu się czytania i pisania (klasa IV-VI, gimnazjum, szkoły ponadgimnazjalne), [w:] Podniesienie efektywności kształcenia uczniów ze specyficznymi potrzebami edukacyjnymi, cz. 1, Warszawa: Ośrodek Rozwoju Edukacji.

Czelakowska D., 2012, Metodyka edukacji polonistycznej dzieci w wieku wczesnoszkolnym, Kraków: Oficyna Wydawnicza Impuls.

DSM-5. Diagnostic and Statistical Manual of Mental Disorders, 2013, Washington-London: American Psychiatric Association. 
ICD-10, 2000, Klasyfikacja zaburzeń psychicznych i zaburzeń zachowania w ICD-10. Opisy kliniczne i wskazówki diagnostyczne, Kraków-Warszawa: Wydawnictwo Vesalius.

Korendo M., 2009, Dysleksja - problem wciąż nieznany, „Studia Pedagogiczne Uniwersytetu Humanistyczno-Przyrodniczego Jana Kochanowskiego", t. 18, s. 231-241.

Kowaluk-Romanek M., 2016, Dysleksja. Czy taki diabet straszny, jak go malują?, „Lubelski Rocznik Pedagogiczny", t. XXXV, z. 3, s. 305-320.

Krasowicz-Kupis G., 2009a, Psychologia dysleksji, Warszawa: Wydawnictwo Naukowe PWN.

Krasowicz-Kupis G. (red.), 2009b, Diagnoza dysleksji. Najważniejsze problemy, Gdańsk: Wydawnictwo Harmonia.

Kurowska B., 2011, Dziecko ryzyka dysleksji w przedszkolu, Kraków: Wydawnictwo Naukowe Uniwersytetu Pedagogicznego.

Łockiewicz M., Bogdanonwicz K.M., 2013, Dysleksja u osób dorosłych, Kraków: Oficyna Wydawnicza Impuls.

Nijakowska J., 2004, Usprawnianie umiejętności odczytywania i zapisywania wyrazów w języku angielskim młodzieży z dysleksja rozwojowa, [w:] M. Bogdanowicz, M. Smoleń (red.), Dysleksja w kontekście nauczania języków obcych, Gdańsk: Wydawnictwo Harmonia, s. 144-157.

Słownik języka polskiego PWN, https://sjp.pwn.pl (dostęp: 28.11.2019).

Szurek M.M., 2014, Dysleksja istnieje naprawdę! - Jak ją rozpoznać i zrozumieć, „Edukacja Elementarna w Teorii i Praktyce", t. 33, nr 3, s. 153-174.

Wejner-Jaworska T., 2019, Dysleksja z perspektywy dorosłości, Warszawa: Wydawnictwo Difin.

Wróbel T., 1979, Pismo i pisanie w nauczaniu początkowym, Warszawa: Wydawnictwa Szkolne i Pedagogiczne.

\section{Streszczenie}

Artykuł podejmuje wątek deficytów językowych wynikających z dysleksji, dotyczących osób dorosłych i manifestujących się zaburzeniami języka pisanego. Tym samym próbuje odejść od tradycji badań nad dysleksją, które w większości koncentrują się na okresie nauki szkolnej i problemach edukacyjnych. Oprócz wybiórczej analizy językoznawczej próbek tekstowych, która stanowi główną część pracy, w tekście zwrócono też uwagę na ogół symptomów występujących u dorosłych z dysleksją, które w znacznym stopniu mogą komplikować codzienne funkcjonowanie.

\section{Abstract}

The article raises the issue of language disability in adults resulting from dyslexia and manifested by written language disorders. This is how it tries to change the tradition of research on dyslexia, which is mostly focused on the school period and educational problems. In addition to the selective linguistic analysis of the text samples - which is the main part of the thesis - the article also looks at the other symptoms generally found in adults with dyslexia, which can significantly complicate the daily functioning. 